\title{
CORRELATION ANALYSIS BETWEEN JAKARTA COMPOSITE INDEX AND LQ45 INDEX WITH NET ASSET VALUE OF EQUITY MUTUAL FUND AND BALANCED MUTUAL FUND
}

\author{
Johan Halim $^{1} \&$ Sherly Meilintan Surya ${ }^{2}$
}

\begin{abstract}
Subprime mortgage is one factor causes world economic in crisis. The impact has stroke the stock exchange world wide, included Indonesia Stock Exchange (BEI).The investors who are investing in the instrument of Stocks and Mutual Fund are having consequences of global financial crisis and index prices drops. In Indonesia, Mutual Fund is guaranteed by the BAPEPAM with the Act of Capital Market no.8, 1995 (Undang-Undang Pasar Modal). The main purposes of the research is to analyze JCI and LQ 45 index with Equity Mutual Fund and Balanced Mutual Fund in terms of risk and return, sharpe ratio, correlation and whether the JCI and LQ 45 are linked together over time with Vector Autoregression (VAR). Types of research methodology are using secondary research method and analysis method. In return, Equity Mutual Fund has a higher return than Balanced Mutual Fund because the portfolio diversification consists of money market and equity, but in Balanced Mutual Fund there is also bond as portfolio. In risk, Equity Mutual Fund is more risky than Balanced Mutual Fund as compensation with higher return. Sharpe ratio is used to measure the performance of mutual fund. The higher the Sharpe ratio, the better the fund's historical risk-adjusted performance. In VAR, both Equity Mutual Fund and Balanced Mutual Fund will affect by both JCI and LQ 45 Index.
\end{abstract}

Keywords: equity mutual fund; balanced mutual fund; risk and return; sharpe ratio; correlation; vector auto regression

\footnotetext{
${ }^{1}$ Senior Manager Strategy \& Performance Group of PT Bank Mandiri, johan.halim@bankmandiri.co.id

${ }^{2}$ BINUS BUSINESS SCHOOL, BINUS UNIVERSITY, JWC Campus, Jl. Hang Lekir I No. 6, Kebayoran Baru, South Jakarta 12120, sherly_ms2001@yahoo.com
} 


\section{BACKGROUND}

The progress of economic in a certain country can be determined with various factors, such internal factor and external factor. First, one that comprise of internal factor are political condition and social of its country, economics that contains of inflation and interest rate factor, and industrial development of home country. Second, external factor are foreign capital from foreign investor, the effects of stock exchange fluctuation in other countries, such Stock Exchange in United States (US) and regional Stock Exchange in Asia, and economic crisis happened in big countries and they affected other countries all around the world such as the crisis of subprime mortgage in US.

According to www.korantempo.com stated that the take-over of Freddie Mac and Fannie Mae by the US government has sparked the subprime crisis by September $8^{\text {th }}, 2008$. The consequence of the subprime mortgage also affects on various investment banks, such as: Lehman Brothers had filed bankruptcy by September $15^{\text {th }}, 2008$ with debt of US\$ 613 Billion, and Bank of America had acquisition Merrill Lynch with value of US\$ 50 Billion. Furthermore, on September $17^{\text {th }}, 2008$ the Bank Central of US has injected AIG (American International Group) insurance company in cash of US\$ 85 Billion. The subprime mortgage has brought unacceptable impact for all stocks market around the world, included Indonesia.

However, subprime mortgage not the only one causes world economic in crisis, more than that is the crude oil price that rises to the high level of $\$ 142$ per barrel. Then, the impact has stroke the stock exchange world wide, included Indonesia Stock Exchange (BEI). Those two crisis maker has put the economic situation up side down and creates higher inflation. The situation is clearly explained by the risen of Bank Indonesia (BI) rate of $9.5 \%$ by October $7^{\text {th }}$, 2008. According to www.finansialbisnis.com stated that, the inflation rate on October 2008 was $0.45 \%$, cumulative $10.96 \%$ and year on year $11.77 \%$. Those rates are not close enough from the expectation as for $6 \%$. At the end of October 2008, the Fed has cut the interest rate of $1.5 \%$ to become $1 \%$ to solve the global financial crisis and bring up fallen stocks because of Subprime mortgage.

Unavoidable, US is in recession. The inflation rate has disturbed US economic, even Indonesia endangers of high inflation rate threats. The uncertain of global economic condition makes BEI shaken. The worst effect of uncertain is shown on October $8^{\text {th }}, 2008$ when the BEI is closed on the second session of trading and it is continued to October $10^{\text {th }}, 2008$, according to www.kompascetak.com.

The investors who are investing in the instrument of Stocks and Mutual Fund are having consequences of global financial crisis and index prices drops. In Indonesia, Mutual Fund is guaranteed by the BAPEPAM with the Act of Capital Market no.8, 1995 (UndangUndang Pasar Modal). As stated in the Act of Capital Market no.8, 1995 says: "All asset of The Mutual Fund are obligated to deposit into the custodian bank with no affiliate to the Investment Manager that manage the Mutual Fund". This statement means, if the Investment Manager filed bankruptcy then the investor's fund will not drag in with, because the fund are save in the custodian bank.

All Mutual Funds has each portfolio that fit with risk and return of the investor will gain. The Mutual Fund that has most influence on the fallen of Jakarta Composite Index (JCI) or JSX Composite are Equity Mutual Fund and Balanced Mutual Fund. The Equity Mutual Fund with minimum portfolio of $80 \%$ on equity when the index has fall, then the Net Asset Value (NAV) of the Mutual Fund will fall as well. In the contrary with the Balanced Mutual Fund with diversified portfolio in equity, government or corporate bonds and money market, 
the impact of the index fall will be minimized by portfolio such as government or corporate bonds and money market.

Moreover, as the background mention before, writer have a great interest to analyze the correlation between the fall of JCI and NAV of Equity Mutual Fund and Balanced Mutual Fund, with Subject: "Correlation Analysis between Jakarta Composite Index and LQ 45 Index with Net Asset Value of Equity Mutual Fund and Balanced Mutual Fund".

\section{PROBLEM IDENTIFICATION}

This study will discuss and develop issues such:

1. Index variable are JCI and LQ 45 become a standard for investor to spend in Balanced Mutual Fund and Equity Mutual Fund.

Hypothesis:

a. Index variable goes up, NAV will go up.

b. Index variable goes down, NAV will go down.

2. One of the characteristics of Mutual Fund is diversified portfolio (Siamat, 2005, page 497).

Balanced Mutual Fund has more diversified portfolio compare to Equity Mutual Fund with the composition of portfolio equity and non equity is government or corporate bond and money market.

Hypothesis: "Diversified portfolio will reduce risk and return."

\section{LITERATURE REVIEW}

According to Act of Capital Market no.8, 1995, the definition of mutual fund is a media that used to gathered public capital funds then be invested in stocks portfolio by investment manager. Types of mutual fund according to Siamat $(2005 ; 492)$ are:

1. Based on regulation, mutual fund are divided into 2 (two) types:

a. Corporate Mutual Fund, has characteristics as:

1) By law is the limited company.

2) Paper endorsed by corporate mutual fund is stock.

3) Portfolio is managing by investment manager based on contract.

4) Administration and saving of portfolio is endorsed and manage with contract by custodian bank.

5) Sponsors are required with minimum deposit of $1 \%$ as a beginning capital.

6) Perform as closed end and opened end.

b. KIK Mutual Fund (Kontrak Investasi Kolektif/Collective Investment Contract), has characteristics as:

1) Stock Index Corporation or others that have trading license as an investment manager from BAPEAM are able to establish KIK Mutual Fund.

2) Stocks endorsed by KIK Mutual Fund called trust unit.

3) Managing of collective investment portfolio is supervised by investment manager.

4) Custodian bank has authority to perform collective deposit.

5) Perform as opened end 
2. Based on the operational performing, mutual fund are divided into 2 (two) types:

a. Closed End Investment Funds

Characteristics of Closed End Investment Funds are:

1) Stocks is listed in Stock Exchange.

2) Price indicator of closed end investment funds is acquired from NAV. NAV are calculated and announced to public only once a week.

3) Closed end investment fund price always under NAV.

4) Only sell mutual fund stocks (not the trust unit as stated on opened mutual fund) to investors up to the beginning capital limit that have been stated on beginning budget of corporation.

5) Investors are unable to resale stocks that bought from related mutual funds with exception resale through stocks house with mechanism of market price.

b. Opened End Investment Funds

Characteristics of Opened End Investment Funds are:

1) Trust units are not listed on stocks house.

2) Buy and Sell's price of trust unit of mutual fund are based on NAV.

3) Investors are able to buy and sell the trust unit based on NAV.

3. Based on the investment portfolio of mutual fund are divided into 4 (four) types:

a. Money Market Mutual Fund

Mutual fund only invests on stocks payable with the due date less than one year.

b. Fixed Income Mutual Fund

Mutual fund invests with minimum investment of $80 \%$ out of asset in the form of stocks payable.

c. Equity Mutual Fund

Mutual fund invests with minimum investment of $80 \%$ in equity or stocks.

d. Balanced Mutual Fund

Mutual fund invests in equity stocks and payable stocks with comparison not included in the category of point $b$ and $c$.

The activity of mutual fund portfolio management can be evaluated from Net Asset Value (NAV) according to Siamat (2005; 499).

Net Asset Value of mutual fund is calculated with a formula as follow:

Total Net Asset Value in certain period:

Total NAV = Asset Value - Total Payable

Net Asset Value per unit: Total Net Asset/Total published joint unit (stocks)

NAV per unit $=\frac{\text { Total net asset }}{\text { Total trust unit (stocks) published }}$

The expected rate of return is a probability weighted averages of the possible outcomes according to Bodie, et al $(2008 ; 134)$.

$$
E(r)=\sum_{s} p(s) r(s)
$$

where:

$\mathrm{E}(\mathrm{r}) \quad=$ expected return

$\mathrm{p}(\mathrm{s}) \quad=$ probability

$\mathrm{r}(\mathrm{s}) \quad=$ return of share 
The standard deviation of the rate of return $(\sigma)$ is a measure of risk according to Bodie, et al (2008; 134). It is defined as the square root of the variance, which in turn is the expected value of the squared deviations from expected return. The higher the volatility in outcomes, the higher will be the average value of these squared deviations. Therefore, variance and standard deviation measure the uncertainty of outcomes.

Symbolically,

Variance $=$ expected value of squared deviations

$$
\sigma^{2}=\sum_{s} p(s)[r(s)-E(r)]^{2}
$$

where:

$\sigma^{2} \quad=$ variance

$\mathrm{E}(\mathrm{r}) \quad=$ expected return

$\mathrm{p}(\mathrm{s}) \quad=$ probability

$\mathrm{r}(\mathrm{s}) \quad=$ return of share

Using historical data with $\mathrm{n}$ observations, we estimate variance as

$$
\begin{gathered}
\sigma^{2}=\frac{1}{n} \sum_{s=1}^{n}[r(s)-\bar{r}]^{2} \\
\sigma=\sqrt{\sigma^{2}}
\end{gathered}
$$

where:

$$
\begin{array}{ll}
\sigma^{2} & =\text { variance } \\
\mathrm{E}(\mathrm{r}) & =\text { expected return } \\
\mathrm{p}(\mathrm{s}) & =\text { probability } \\
\mathrm{r}(\mathrm{s}) & =\text { return of share } \\
\bar{r} & =\text { sample arithmetic average }
\end{array}
$$

There are 2 (two) types of risks according to Berk, Jonathan and De Marzo, Peter, 2007, page 303 are:

1. Systematic risk or non diversifiable risk or market risk

Fluctuations of a stock's return that are due to market wide news represent common risk. Example: As with earthquakes, all stocks are affected simultaneously by the news or Indonesia's Central Bank might announce that it will lower interest rates to boost the economy.

2. Non systematic risk or diversifiable risk

Fluctuations of a stock's return that are due to firm specific news are independent risks. Example: a firm might announce that it has been successful in gaining market share within its industry.

According to Levine, et al $(2005$; 139), the relative strength of a linear relationship or the association between two variables is typically measured by coefficient of correlation. The coefficient of correlation is denoted by the Greek letter $(\rho)$ and the values range from -1 up to +1 . 
The Sample of Coefficient of Correlation ( $r$ )

$$
r=\frac{\sum_{i=1}^{n}(X i-\bar{X})(Y i-\bar{Y})}{\sqrt{\sum_{i=1}^{n}(X i-\bar{X})^{2}} \sqrt{\sum_{i=1}^{n}(Y i-\bar{Y})^{2}}}
$$

where:

$\mathrm{r} \quad=$ coefficient of correlation

$\mathrm{X}_{\mathrm{i}} \quad=\mathrm{i}^{\text {th }}$ observation of the variable

$\bar{X} \quad=$ arithmetic mean of the variable $\mathrm{X}$

$\mathrm{Y}_{\mathrm{i}} \quad=\mathrm{i}^{\text {th }}$ observation of the variable $\mathrm{Y}$

$\bar{Y} \quad=$ arithmetic mean of the variable $\mathrm{Y}$

$\mathrm{n} \quad=$ number of observations or sample size

According to Berk, et al $(2007 ; 327)$, correlation is a barometer of the degree to which the returns share common risk and tend to move together. The closer the correlation is to +1 , the more the returns tend to move together as a result of systematic risk. When the correlation (and thus the covariance) equals 0 , the returns are uncorrelated; that is they have no tendency to move either together or in opposition of one another. Unsystematic risks are uncorrelated. Finally, the closer the correlation to -1 , the more the returns tend to move in opposite directions.

According to Seiler, Michael J., 2004, page 311, Vector Autoregression (VAR) is used to model multiple variables that are linked together over time. Instead of specifying a dependent variable in terms of several other independent variables, the independent variables used in VAR are simply lags of the various interrelated dependent variables.

For example, assume we recognize the existence of an interrelationship among five different time series: unsecuritized real estate, securitized real estate, stocks, corporate bonds and government bonds. If we want to model the returns on unsecuritized real estate, we could model it as a function of lags of unsecuritized real estate, securitized real estate, stocks, corporate bonds and government bonds. In short, VAR bypasses the development of a structural equation by specifying a model in terms of lags in all the variables included in an interrelated system.

According to Eviews User Guide, Vector Autoregression (VAR) is commonly used for forecasting systems of interrelated time series and for analyzing the dynamic impact of random disturbances on the system of variables. The VAR approach sidesteps the need for structural modeling by treating every endogenous variable in the system as a function of the lagged values of all of the endogenous variables in the system. The mathematical representation of a VAR is:

$$
y_{t}=A_{1} y_{t-1}+\ldots+A_{p} y_{t-p}+B x_{t}+\varepsilon_{t}
$$

where:

$\mathrm{y}_{\mathrm{t}}=\mathrm{k}$ vector of endogenous variables 
$\mathrm{x}_{\mathrm{t}}=\mathrm{d}$ vector of exogenous variables

$\mathrm{A}_{1}, \ldots, \mathrm{A}_{\mathrm{p}}$ and $\mathrm{B}=$ matrices of coefficients to be estimated

$\varepsilon_{\mathrm{t}}=\mathrm{a}$ vector of innovations that may be contemporaneously correlated but are uncorrelated with their own lagged values and uncorrelated with all of the right hand side variables.

\section{RESEARCH METHODOLOGY}

The methods of the research are using Pearson Correlation to uncover the strength of its relation and also the uses of Vector Autoregression to determine the effect of independent variable through dependent variable.

The research is using index variable data of Jakarta Composite Index and LQ 45 Index for the periods January 2004 - December 2008 with daily data frequency. Other data used are Net Asset Value of Balanced Mutual Fund and Equity Mutual Fund from 10 Indonesian's Investment Manager, sources: www.infovesta.com. Then, after all the necessary data for the research has been collected follow by processing through the calculation.

Hypothesis testing is one of procedure will come out with one decision which is accepted or rejected.

1. Hypotheses are used for correlation:

a. Hypothesis a

$\mathrm{H}_{0}$ : there is a correlation between Jakarta Composite Index (JCI) with NAV of Balanced Mutual Fund.

$\mathrm{H}_{1}$ : there is no correlation between JCI with NAV of Balanced Mutual Fund.

b. Hypothesis b

$\mathrm{H}_{0}$ : there is a correlation between LQ 45 Index with NAV of Balanced Mutual Fund.

$\mathrm{H}_{1}$ : there is no correlation between LQ 45 Index with NAV of Balanced Mutual Fund.

c. Hypothesis c

$\mathrm{H}_{0}$ : there is a correlation between Jakarta Composite Index (JCI) with NAV of Equity

Mutual Fund.

$\mathrm{H}_{1}$ : there is no correlation between JCI with NAV of Equity Mutual Fund.

d. Hypothesis d

$\mathrm{H}_{0}$ : there is a correlation between LQ 45 Index with NAV of Equity Mutual Fund.

$\mathrm{H}_{1}$ : there is no correlation between LQ 45 Index with NAV of Equity Mutual Fund.

2. Hypotheses are used for vector autoregression:

a. Hypothesis a

$\mathrm{H}_{0}$ : there is an effect from Jakarta Composite Index (JCI) to NAV of Balanced Mutual

Fund.

$\mathrm{H}_{1}$ : there is no effect from JCI to NAV of Balanced Mutual Fund.

b. Hypothesis b

$\mathrm{H}_{0}$ : there is an effect from LQ 45 Index to NAV of Balanced Mutual Fund.

$\mathrm{H}_{1}$ : there is no effect from LQ 45 Index to NAV of Balanced Mutual Fund.

c. Hypothesis c

$\mathrm{H}_{0}$ : there is an effect from Jakarta Composite Index (JCI) to NAV of Equity Mutual

Fund.

$\mathrm{H}_{1}$ : there is no effect from JCI to NAV of Equity Mutual Fund.

d. Hypothesis d 
$\mathrm{H}_{0}$ : there is an effect from LQ 45 Index to NAV of Equity Mutual Fund.

$\mathrm{H}_{1}$ : there is no effect from LQ 45 Index to NAV of Equity Mutual Fund.

\begin{abstract}
ANALYSIS
Analysis section will analyze the correlation from NAV of Balanced Mutual Fund and Equity Mutual Fund with Jakarta Composite Index and LQ 45 Index. The analysis also used Vector Autoregression which applied regression from NAV of mutual fund as a dependent variable with Jakarta Composite Index and LQ 45 index as an independent variable. The result of the research processed with Eviews ver. 4.1 program and developed data with Microsoft Excel 2003 program.

According to http://en.wikipedia.org "The global financial crisis of $2008-2009$ is an ongoing major financial crisis. It became prominently visible in September 2008 with the failure, merger, or conservatorship of several large United States-based financial firms." The effects of stock exchange fluctuation in other countries, such Stock Exchange in United States (US) and regional Stock Exchange in Asia, and economic crisis happened in big countries and they affected other countries all around the world such as the crisis of subprime mortgage in US. This situation becomes a domino effect for Indonesia and has many impacts to Indonesia's economy especially financial sector. It can be categorized as systematic risk or market risk.

According to www.bapepam.go.id, the growth of Mutual Fund in 2000 until 2005 can be seen from Net Asset Value' s growth and total investors. The increasing of NAV was started in 2004 with total amount IDR 110 billion and it continued until February 2005. Later the decreasing of NAV was started in third quarter of 2005 and it is included the total of investors.

The decrements run in line with macroeconomic condition in Indonesia. Some of indicators had shown decreased movements from January until December 2005. Some of indicators are depreciating IDR against USD with the highest at IDR 12,000/USD, highest oil price at USD 71/ barrel in the end of August 2005, inflation in the end of October 2005 was $15.65 \%$ and SBI rate was $11 \%$. In addition to, Bank Central of Indonesia committed to do Tight Money Policy and increased Minimum Reserve for banks to reduce the liquidity in the market. The increasing of interest rate had an impact to the decreasing of bond price which is it became a portfolio of mutual fund. The decreasing of bond price affected the return of mutual fund and this situation encourages investor to do redemption.

For Balanced Mutual Fund and Equity Mutual Fund, we select 10 (ten) investment managers which have the biggest market capitalization in Indonesia. From each investment manager, we select one product of Balanced Mutual Fund and Equity Mutual Fund which has the biggest fund size.
\end{abstract}


Table 1. List of Balanced Mutual Fund

\begin{tabular}{|c|c|c|}
\hline No. & Product & Launched Date \\
\hline 1 & Schroder Dana Terpadu II & 18 May 2006 \\
\hline 2 & Fortis Spektra & 14 June 2005 \\
\hline 3 & Mandiri Investasi Aktif & 24 March 2005 \\
\hline 4 & Batavia Si Dana Dinamis & 5 January 2004 \\
\hline 5 & Manulife Dana Campuran & 1 August 2003 \\
\hline 6 & Bahana Dana Infrastruktur & 27 May 1997 \\
\hline 7 & Danareksa Anggrek & 7 March 1996 \\
\hline 8 & Optima Fleksi & 7 July 2005 \\
\hline 9 & Simas Danamas Fleksi & 30 March 2005 \\
\hline 10 & BNI Dana Fleksibel Dua & 2 January 2007 \\
\hline
\end{tabular}

Table 2. List of Equity Mutual Fund

\begin{tabular}{|c|c|c|}
\hline No. & Product & Launched Date \\
\hline 1 & Schroder Dana Prestasi Plus & 25 September 2000 \\
\hline 2 & Fortis Ekuitas & 28 February 2001 \\
\hline 3 & Mandiri Investasi Atraktif & 30 August 2005 \\
\hline 4 & Batavia Si Dana Saham & 1 August 2003 \\
\hline 5 & Manulife Dana Saham & 1 August 2003 \\
\hline 6 & Bahana Dana Prima & 8 August 1996 \\
\hline 7 & Danareksa Mawar Agresif & 16 July 2007 \\
\hline 8 & Optima Saham & 15 September 2002 \\
\hline 9 & Simas Danamas Saham & 5 October 2007 \\
\hline 10 & BNI Reksadana Berkembang & 15 May 2003 \\
\hline
\end{tabular}

Table 3. BI Rate as Risk Free Rate

\begin{tabular}{|c|c|c|c|c|c|}
\cline { 2 - 6 } \multicolumn{1}{c|}{} & Dec-04 & Dec-05 & Dec-06 & Dec-07 & Dec-08 \\
\hline Risk Free Rate & $7.43 \%$ & $12.75 \%$ & $9.75 \%$ & $8.00 \%$ & $9.25 \%$ \\
\hline
\end{tabular}




\section{Risk of All Product of Balanced Mutual Fund}



Figure1. Return of All Product of Balanced Mutual Fund 
Sharpe Ratio of All Product of Balanced Mutual Fund

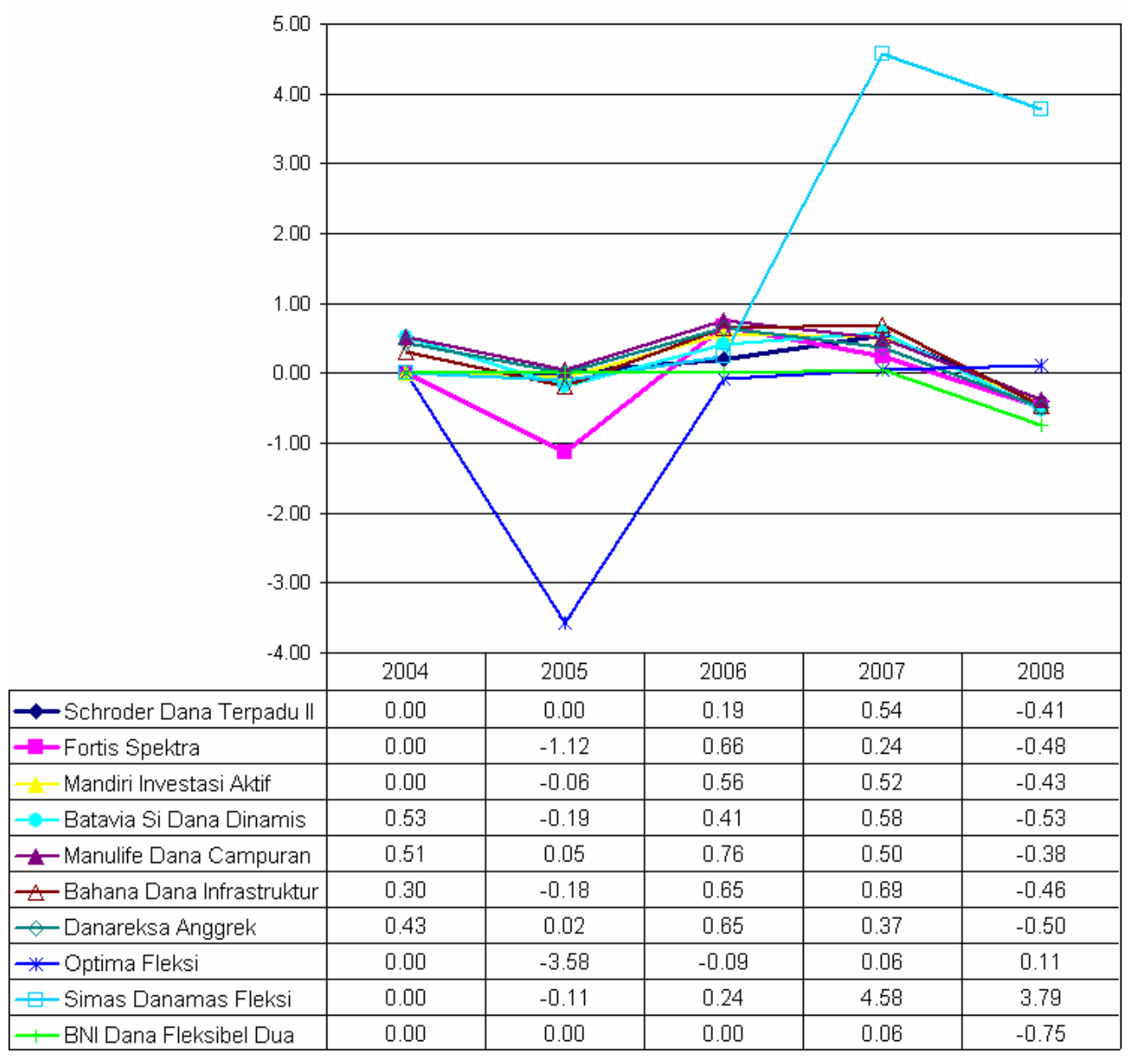

Figure 2. Sharpe Ratio of All Product of Balanced Mutual Fund 
Table 4. Correlation Matrix of All Product of Balanced Mutual Fund

\begin{tabular}{|c|c|c|c|}
\hline \multirow{2}{*}{ No } & \multirow{2}{*}{ Product } & \multicolumn{2}{|c|}{ Coefficient of Correlation } \\
\cline { 3 - 4 } & & JCI & \multicolumn{1}{c|}{ LQ45 } \\
\hline 1 & Schroder Dana Terpadu II & 0.927080 & 0.888098 \\
\hline 2 & Fortis Spektra & 0.959033 & 0.947832 \\
\hline 3 & Mandiri Investasi Aktif & 0.998081 & 0.992714 \\
\hline 4 & Batavia Si Dana Dinamis & 0.980887 & 0.985281 \\
\hline 5 & Manulife Dana Campuran & 0.991121 & 0.985641 \\
\hline 6 & Bahana Dana Infrastruktur & 0.982162 & 0.978692 \\
\hline 7 & Danareksa Anggrek & 0.990448 & 0.985724 \\
\hline 8 & Optima Fleksi & 0.902354 & 0.892270 \\
\hline 9 & Simas Danamas Fleksi & 0.717848 & 0.664982 \\
\hline 10 & BNI Dana Fleksibel Dua & 0.649915 & 0.676310 \\
\hline
\end{tabular}

In this vector autoregression estimates, we use 2 lags analysis and 4 lags analysis. Lags is entered in pairs, each pair of numbers defines a range of lags. For example: 12 (called as 2 lags) tells EViews to use the first through two lags of all the endogenous variables in the system as right-hand side variables. 14 (called as 4 lags) tells EViews to use the first through fourth lags of all the endogenous variables in the system as right-hand side variables. To determine $t_{\text {table, }}$ we use level of significance $5 \%$, where $\mathrm{df}=\mathrm{n}-1 ; \mathrm{n}=$ total samples. So, we will get $t_{\text {table }}=1.96$. 
Table 5. Vector Autoregression of All Product of Balanced Mutual Fund with 2 lags and 4 lags

\begin{tabular}{|c|c|c|c|c|c|c|c|c|c|c|c|c|}
\hline & \multicolumn{6}{|c|}{ 1. Schuroder Dana Terpadu II } & \multicolumn{6}{|c|}{ 2. Fortis Spektra } \\
\hline & \multicolumn{3}{|c|}{ JCI } & \multicolumn{3}{|c|}{ LQ 45 } & \multicolumn{3}{|c|}{ JCI } & \multicolumn{3}{|c|}{ LQ 45 } \\
\hline 2 Lags & t-statistic & t - table & Status & t- statistic & $t$ - table & Status & t-statistic & t - table & Status & t-statistic & t - table & Status \\
\hline Lag 1 & 4.15274 & 1.96 & Accept H1 & 3.82025 & 1.96 & Accept H1 & 1.56334 & 1.96 & Accept HO & 1.12525 & 1.96 & Accept HO \\
\hline Lag 2 & -4.31093 & 1.96 & Accept HO & -3.97089 & 1.96 & Accept HO & -1.31525 & 1.96 & Accept HO & -0.89374 & 1.96 & Accept HO \\
\hline 4 Lags & t-statistic & t - table & Status & t-statistic & $t$ - table & Status & t-statistic & t- table & Status & t-statistic & t- table & Status \\
\hline Lag 1 & 3.68564 & 1.96 & Accept H1 & 3.33381 & 1.96 & Accept H1 & 1.55111 & 1.96 & Accept HO & 1.15181 & 1.96 & Accept HO \\
\hline Lag 2 & -3.20152 & 1.96 & Accept HO & -2.95752 & 1.96 & Accept HO & -0.33921 & 1.96 & Accept HO & -0.18342 & 1.96 & Accept HO \\
\hline Lag 3 & -0.41420 & 1.96 & Accept HO & -0.44708 & 1.96 & Accept HO & -0.52079 & 1.96 & Accept HO & -0.39414 & 1.96 & Accept HO \\
\hline \multirow[t]{3}{*}{$\operatorname{Lag} 4$} & 1.05726 & 1.96 & Accept HO & 1.14064 & 1.96 & Accept HO & -0.07547 & 1.96 & Accept HO & -0.09293 & 1.96 & Accept HO \\
\hline & \multicolumn{6}{|c|}{ 3. Mandiri Investa Aktif } & \multicolumn{6}{|c|}{ 4. Batavia Si Dana Dinamis } \\
\hline & \multicolumn{3}{|c|}{ JCI } & \multicolumn{3}{|c|}{ LQ 45 } & \multicolumn{3}{|c|}{ JCI } & \multicolumn{3}{|c|}{ LQ 45 } \\
\hline 2 Lags & t-statistic & t - table & Status & t-statistic & t - table & Status & t-statistic & t - table & Status & t-statistic & t - table & Status \\
\hline Lag 1 & 2.00692 & 1.96 & Accept H1 & 1.50850 & 1.96 & Accept HO & 0.92369 & 1.96 & Accept HO & 0.58555 & 1.96 & Accept HO \\
\hline Lag 2 & -2.24102 & 1.96 & Accept HO & -1.74618 & 1.96 & Accept HO & -0.74867 & 1.96 & Accept HO & -0.39079 & 1.96 & Accept HO \\
\hline 4 Lags & t-statistic & t - table & Status & t- statistic & t - table & Status & t-statistic & t - table & Status & t- statistic & t - table & Status \\
\hline$\overline{\operatorname{Lag} 1}$ & 1.91614 & 1.96 & Accept HO & 1.47832 & 1.96 & Accept HO & 0.97585 & 1.96 & Accept HO & 0.64834 & 1.96 & Accept HO \\
\hline Lag 2 & -0.95821 & 1.96 & Accept HO & -0.69818 & 1.96 & Accept HO & -1.03079 & 1.96 & Accept HO & -0.77944 & 1.96 & Accept HO \\
\hline Lag 3 & -0.0172 & 1.96 & Accept HO & 0.16085 & 1.96 & Accept HO & 0.01148 & 1.96 & Accept HO & 0.19838 & 1.96 & Accept HO \\
\hline \multirow[t]{3}{*}{ Lag 4} & -0.82635 & 1.96 & Accept HO & -1.01116 & 1.96 & Accept HO & 0.69130 & 1.96 & Accept HO & 0.39809 & 1.96 & Accept HO \\
\hline & \multicolumn{6}{|c|}{ 5. Manulife Dana Canquran } & \multicolumn{6}{|c|}{ 6. Bahana Dana Infrastruktur } \\
\hline & \multicolumn{3}{|c|}{ JCI } & \multicolumn{3}{|c|}{ LQ 45 } & & JCI & & & LQ 45 & \\
\hline 2 Lags & t-statistic & t - table & Status & t- statistic & $t$ - table & Status & t-statistic & t - table & Status & t- statistic & t - table & Status \\
\hline Lag 1 & 4.42832 & 1.96 & Accept H1 & 4.02015 & 1.96 & Accept H1 & 0.77846 & 1.96 & Accept HO & 0.71896 & 1.96 & Accept HO \\
\hline Lag 2 & -4.33491 & 1.96 & Accept HO & -3.92103 & 1.96 & Accept HO & -0.99285 & 1.96 & Accept HO & -0.93340 & 1.96 & Accept HO \\
\hline 4 Lags & -statistic & t - table & Status & t- statistic & $t$ - table & Status & t-statistic & t - table & Status & t-statistic & t- table & Status \\
\hline Lag 1 & 4.3025 & 1.96 & Accept H1 & 3.95837 & 1.96 & Accept H1 & 0.54272 & 1.96 & Accept HO & 0.53056 & 1.96 & Accept HO \\
\hline Lag 2 & -1.63277 & 1.96 & Accept HO & -1.43509 & 1.96 & Accept HO & 0.23504 & 1.96 & Accept HO & 0.17183 & 1.96 & Accept HO \\
\hline Lag 3 & -1.52157 & 1.96 & Accept HO & -1.47579 & 1.96 & Accept HO & -0.88878 & 1.96 & Accept HO & -0.67173 & 1.96 & Accept HO \\
\hline Lag 4 & 0.47545 & 1.96 & Accept HO & 0.45973 & 1.96 & Accept HO & -0.19051 & 1.96 & Accept $\mathrm{HO}$ & -0.02608 & 1.96 & Accept HO \\
\hline & & & 7.Dantarek & sa Anggrek & & & & & 8. Optim & na Fleksi & & \\
\hline & & JCI & & & LQ 45 & & & JCI & & & LQ 45 & \\
\hline 2 Lags & t- statistic & t - table & Status & $\mathbf{t}$ - statistic & t- table & Status & t-statistic & t - table & Status & t- statistic & t- table & Status \\
\hline Lag 1 & 3.23060 & 1.96 & Accept H1 & 3.02587 & 1.96 & Accept H1 & 0.76422 & 1.96 & Accept HO & 0.75446 & 1.96 & Accept HO \\
\hline Lag 2 & -3.30541 & 1.96 & Accept HO & -3.10544 & 1.96 & Accept HO & 1.24498 & 1.96 & Accept HO & 1.20097 & 1.96 & Accept HO \\
\hline 4 Lags & t-statistic & t - table & Status & t - statistic & t- table & Status & t-statistic & t - table & Status & t- statistic & t - table & Status \\
\hline$\overline{\operatorname{Lag} 1}$ & 3.19227 & 1.96 & Accept H1 & 3.00990 & 1.96 & Accept H1 & 1.16082 & 1.96 & Accept HO & 1.08110 & 1.96 & Accept HO \\
\hline Lag 2 & -2.03903 & 1.96 & Accept HO & -1.87332 & 1.96 & Accept HO & 1.59009 & 1.96 & Accept $\mathrm{HO}$ & 1.48993 & 1.96 & Accept HO \\
\hline Lag 3 & 0.12112 & 1.96 & Accept HO & 0.12004 & 1.96 & Accept HO & -0.13208 & 1.96 & Accept HO & -0.09855 & 1.96 & Accept HO \\
\hline Lag 4 & -0.67304 & 1.96 & Accept HO & -0.72124 & 1.96 & Accept HO & -1.05932 & 1.96 & Accept HO & -0.92450 & 1.96 & Accept HO \\
\hline & & & 9. Simas Da & namas Fleks & & & & & D. BNI Dana & Fleksibel D & & \\
\hline & & JCI & & & LQ 45 & & & JCI & & & LQ 45 & \\
\hline \begin{tabular}{|l|}
2 Lags \\
\end{tabular} & t-statistic & t - table & Status & t - statistic & t - table & Status & t-statistic & t - table & Status & t- statistic & t - table & Status \\
\hline Lag 1 & 0.43026 & 1.96 & Accept HO & 0.53897 & 1.96 & Accept HO & -0.93813 & 1.96 & Accept HO & -0.81366 & 1.96 & Accept HO \\
\hline Lag 2 & -0.48283 & 1.96 & Accept HO & -0.59371 & 1.96 & Accept HO & 1.0209 & 1.96 & Accept $\mathrm{HO}$ & 0.89353 & 1.96 & Accept HO \\
\hline 4 Lags & t-statistic & t - table & Status & t - statistic & t- table & Status & t-statistic & t - table & Status & t-statistic & t - table & Status \\
\hline Lag 1 & 0.61882 & 1.96 & Accept HO & 0.66157 & 1.96 & Accept HO & -1.01269 & 1.96 & Accept HO & -0.90070 & 1.96 & Accept HO \\
\hline Lag 2 & -1.25795 & 1.96 & Accept HO & -1.15313 & 1.96 & Accept HO & 1.41563 & 1.96 & Accept HO & 1.30912 & 1.96 & Accept HO \\
\hline Lag 3 & 1.06996 & 1.96 & Accept HO & 0.71606 & 1.96 & Accept HO & -0.80840 & 1.96 & Accept HO & 0.78364 & 1.96 & Accept HO \\
\hline Lag 4 & -0.39889 & 1.96 & Accept HO & -0.07918 & 1.96 & Accept HO & 0.24022 & 1.96 & Accept HO & 0.2423 & 1.96 & Accept HO \\
\hline
\end{tabular}




\section{Return of All Product of Equity Mutual Fund}

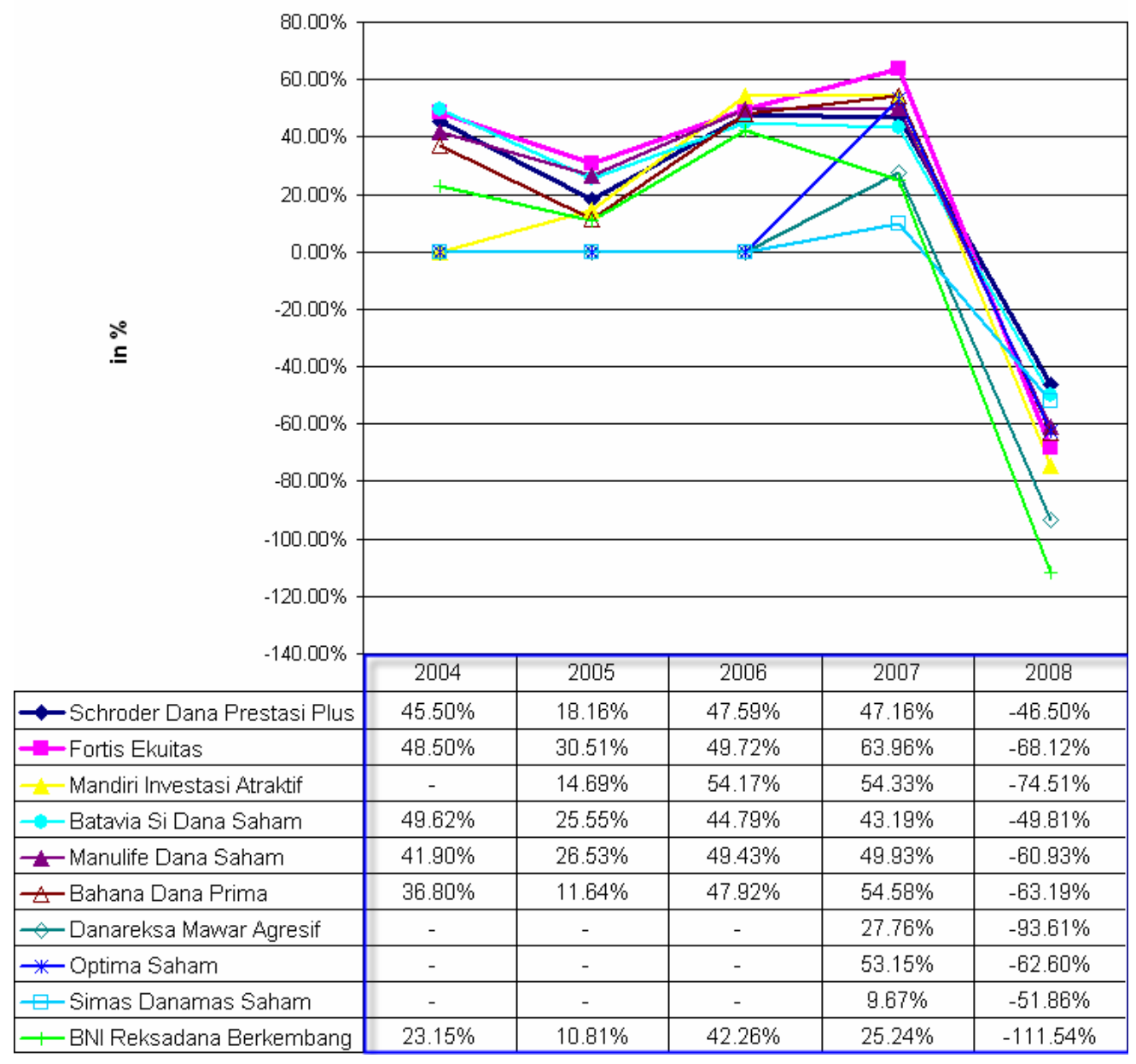

Figure 3. Return of All Product of Equity Mutual Fund 
Risk of All Product of Equity Mutual Fund



Figure 4. Risk of All Product of Equity Mutual Fund 
Sharpe Ratio of All Product of Equity Mutual Fund

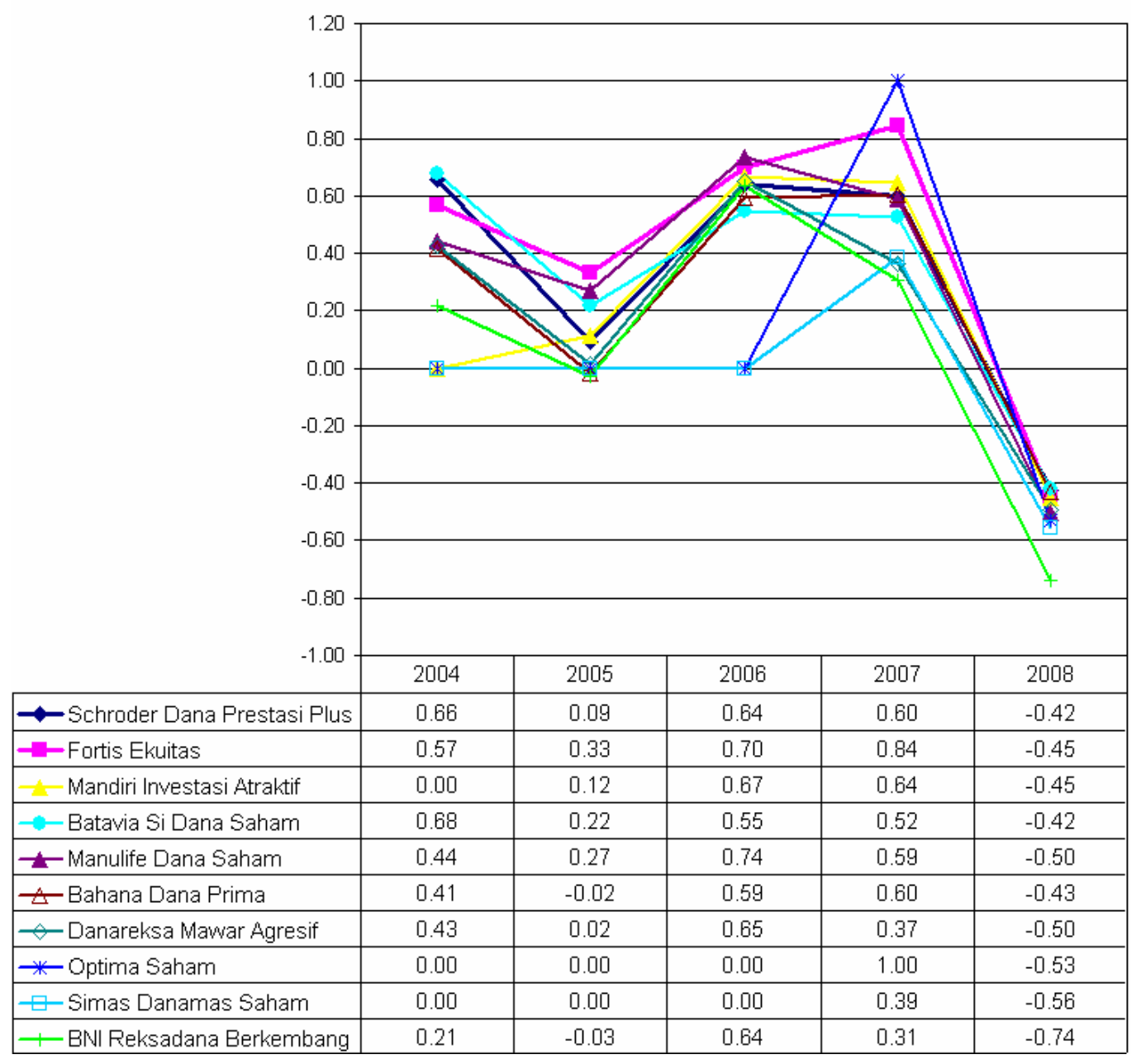

Figure 5. Sharpe Ratio of All Product of Equity Mutual Fund 
Table 6. Correlation Matrix of All Product of Equity Mutual Fund

\begin{tabular}{|c|c|c|c|}
\hline \multirow{2}{*}{ No } & \multirow{2}{*}{ Product } & \multicolumn{2}{|c|}{ Coefficient of Correlation } \\
\cline { 3 - 4 } & & JCI & \multicolumn{1}{c|}{ LQ45 } \\
\hline 1 & Schroder Dana Prestasi Flus & 0.994775 & 0.988618 \\
\hline 2 & Fortis Elritas & 0.995492 & 0.990886 \\
\hline 3 & Mandiri Investasi Atraktif & 0.995668 & 0.994879 \\
\hline 4 & Batavia Si Dana Saham & 0.988745 & 0.988312 \\
\hline 5 & Marnulife Dana Saham & 0.997536 & 0.994297 \\
\hline 6 & Bahana Dana Prima & 0.995649 & 0.995049 \\
\hline 7 & Danareksa Mawar Agresif & 0.990610 & 0.988993 \\
\hline 8 & Optima Saham & 0.984237 & 0.981528 \\
\hline 9 & Simas Danamas Saham & 0.991536 & 0.987238 \\
\hline 10 & BNI Reksadana Berkembang & 0.865286 & 0.887291 \\
\hline
\end{tabular}


Table 7. Vector Autoregression of All Product of Equity Mutual Fund

\begin{tabular}{|c|c|c|c|c|c|c|c|c|c|c|c|c|}
\hline & \multicolumn{6}{|c|}{ 1. Schroder Dana Prestasi Plus } & \multicolumn{6}{|c|}{ 2. Fortis Ekuitas } \\
\hline & \multicolumn{3}{|c|}{ JCI } & \multicolumn{3}{|c|}{ LQ 45 } & \multicolumn{3}{|c|}{ JCI } & \multicolumn{3}{|c|}{ LQ 45 } \\
\hline 2 Lags & t-statistic & $t$ - table & Status & t-statistic & t- table & Status & t-statistic & t- table & Status & -statistic & t- table & Status \\
\hline Lag 1 & 4.32254 & 1.96 & Accept H1 & 3.65684 & 1.96 & Accept H1 & 1.82917 & 1.96 & Accept HO & 1.92241 & 1.96 & Accept HO \\
\hline Lag 2 & -4.49204 & 1.96 & Accept HO & -3.79833 & 1.96 & Accept HO & -1.90385 & 1.96 & Accept HO & -1.97163 & 1.96 & Accept HO \\
\hline 4 Lags & & $t$ - table & Status & & t- table & Status & & table & Status & & table & Status \\
\hline Lag 1 & 6262 & 1.96 & Accept H1 & 3.44391 & 1.96 & Accept H1 & 70552 & 1.96 & Accept HO & 1.82590 & 1.96 & Accept HO \\
\hline $\operatorname{Lag} 2$ & -2.7312 & 1.96 & Accept HO & -2.16397 & 1.96 & Accept HO & .06973 & 1.96 & Accept HO & -0.09405 & 1.96 & Accept HO \\
\hline $\operatorname{Lag} 3$ & -0.33077 & 1.96 & Accept HO & -0.44015 & 1.96 & Accept HO & 1.87996 & 1.96 & Accept HO & -0.75862 & 1.96 & Accept HO \\
\hline \multirow[t]{3}{*}{ Lag 4} & 4916 & 1.96 & Accept HO & 0.04668 & 1.96 & Accept HO & 65669 & 1.96 & Accept HO & -0.69342 & 1.96 & \\
\hline & \multicolumn{6}{|c|}{ 3. Mandiri Investa Atraktif } & \multicolumn{6}{|c|}{ 4. Batavia Si Dana Saham } \\
\hline & \multicolumn{3}{|c|}{ JCI } & \multicolumn{3}{|c|}{ LQ 45} & \multicolumn{3}{|c|}{ JCI } & \multicolumn{3}{|c|}{ LQ 45} \\
\hline 2 Lags & tic & t - table & Status & stic & t-table & us & stic & - table & is & istic & t- table & tus \\
\hline Lag 1 & & 1.96 & Accept HO & -0.5 & 1.96 & Accept HO & & 1.96 & Accept HO & 6919 & 1.96 & $\mathrm{tHO}$ \\
\hline Lag 2 & -0.18180 & 1.96 & Accept HO & 0.34854 & 1.96 & Accept HO & 0.28961 & 1.96 & Accept HO & 0.62353 & 1.96 & Accept HO \\
\hline 4 Lags & statistic & t- table & Status & statistic & t-table & Status & statistic & table & Status & t - statistic & table & Status \\
\hline Lag 1 & & 1.96 & Accept HO & & 1.96 & Acc & & 1.96 & Acc & 956 & 1.96 & t $\mathrm{HO}$ \\
\hline Lag 2 & & 1.96 & Accept HO & & 1.96 & ot $\mathrm{HO}$ & & 1.96 & Accept HO & 044 & 1.96 & $\mathrm{tHO}$ \\
\hline $\operatorname{Lag} 3$ & 7991 & 1.96 & Accept HO & 164 & 1.96 & Accept HO & 087 & 1.96 & Accept HO & 5136 & 1.96 & pt HO \\
\hline \multirow[t]{3}{*}{ Lag 4} & & 1.96 & Accept HO & -0.65591 & 1.96 & Accept HO & & 1.96 & Accept $\mathrm{HO}$ & 0.08705 & 1.96 & ot $\mathrm{HO}$ \\
\hline & \multicolumn{6}{|c|}{ 5. Manulife Dana Saham } & \multicolumn{6}{|c|}{ 6. Bahana Dana Prima } \\
\hline & \multicolumn{3}{|c|}{ JCI } & \multicolumn{3}{|c|}{ LQ 45} & & JCI & & & Q45 & \\
\hline 2 Lags & tic & t- table & Status & tic & t- table & us & stic & t- table & & istic & t-table & us \\
\hline Lag 1 & & 1.96 & Acc & & 1.96 & t Ho & 414 & 1.96 & Acc & 4366 & 1.96 & tH1 \\
\hline Lag 2 & -2.20150 & 1.96 & Accept HO & -1.95738 & 1.96 & Accept HO & -2.66779 & 1.96 & Accept HO & -2.33581 & 1.96 & $\mathrm{tHO}$ \\
\hline 4 Lags & statistic & $t$ - table & Status & stic & t- table & us & stic & able & St & -statistic & able & \\
\hline Lag 1 & & 1.96 & tH1 & & 1.96 & $\mathrm{H} 1$ & & 1.96 & $\mathrm{Ac}$ & 8845 & 1.96 & tH1 \\
\hline $\operatorname{ag} 2$ & & 1.96 & t HO & & 1.96 & t Ho & & 1.96 & Acc & & 1.96 & t HO \\
\hline $\operatorname{Lag} 3$ & 588 & 1.96 & Acce & & 1.96 & Acc & 344 & 1.96 & Acce & 560 & 1.96 & $\mathrm{HO}$ \\
\hline ag 4 & 895 & 1.96 & Accept HO & -0.77378 & 1.96 & Acc & 391 & 1.96 & Accept HO & 29120 & 1.96 & $\mathrm{tHO}$ \\
\hline & & & Danareksa & Mawar Agre & esif & & & & & & & \\
\hline & & JCI & & & LQ 45 & & & JCI & & & & \\
\hline 2 Lags & tic & t- table & atus & tic & t - table & us & stic & - table & & istic & t- table & \\
\hline Lag 1 & 424 & 1.96 & Accept HO & 3117 & 1.96 & Accept HO & 3124 & 1.96 & Accept HO & 0010 & 1.96 & at $\mathrm{HO}$ \\
\hline Lag 2 & 6783 & 1.96 & Accept HO & 1.67997 & 1.96 & Accept HO & -0.94690 & 1.96 & Accept HO & -0.87612 & 1.96 & ot $\mathrm{HO}$ \\
\hline 4 Lags & statistic & $t$ - table & Status & t - statistic & t-table & Status & -statistic & table & Status & - statistic & able & atus \\
\hline Lag 1 & 5309 & 1.96 & Accept HO & -1.39199 & 1.96 & Accept HO & 1799 & 1.96 & Accept HO & 0.66941 & 1.96 & Accept HO \\
\hline Lag 2 & & 1.96 & Accept HO & & 1.96 & Accept HO & & 1.96 & Accept HO & 1110 & 1.96 & $\mathrm{pt} \mathrm{HO}$ \\
\hline Lag 3 & & 1.96 & Accept HO & & 1.96 & Accept HO & & 1.96 & Acce & & 1.96 & $\mathrm{HO}$ \\
\hline Lag 4 & 474 & 1.96 & Accept HO & -0.51541 & 1.96 & Accept HO & 549 & 1.96 & Accept HO & -0.13758 & 1.96 & Accept HO \\
\hline & & & . Simas Da & nas Saha & & & & $10 . \mathrm{B}$ & BNI Reksad & ana Berkeml & & \\
\hline & & JCI & & & LQ 45 & & & JCI & & & LQ 45 & \\
\hline 2 Lags & stic & t - table & Status & statistic & t-table & Status & stic & - table & St & istic & t - table & \\
\hline Lag 1 & 1.15303 & 1.96 & Accept HO & 0.97865 & 1.96 & Accept HO & -0.46988 & 1.96 & Accept HO & -0.72960 & 1.96 & Accept HO \\
\hline Lag 2 & -0.43184 & 1.96 & Accept HO & -0.34878 & 1.96 & Accept HO & 0.65317 & 1.96 & Accept HO & 0.90837 & 1.96 & Accept HO \\
\hline 4 Lags & statistic & $t$ - table & Status & t-statistic & t-table & Status & -statistic & able & Status & - statistic & table & Status \\
\hline Lag 1 & 1.08379 & 1.96 & Accept HO & 0.90469 & 1.96 & Accept HO & -0.63889 & 1.96 & Accept HO & -0.92662 & 1.96 & Accept HO \\
\hline Lag 2 & 0.19743 & 1.96 & Accept HO & 0.14962 & 1.96 & Accept HO & 2.07477 & 1.96 & Accept $\mathrm{H} 1$ & 2.28781 & 1.96 & Accept H1 \\
\hline $\operatorname{Lag} 3$ & & 1.96 & Accept HO & -0.68375 & 1.96 & Accept HO & & 1.96 & Accept HO & -1.36024 & 1.96 & Accept HO \\
\hline Lag 4 & 0.53480 & 1.96 & Accept HO & 0.59612 & 1.96 & Accept HO & -0.18727 & 1.96 & Accept HO & -0.22144 & 1.96 & Accept HO \\
\hline
\end{tabular}

\section{CONCLUSION}

From analysis and solution in Chapter IV, we can conclude as follows:

\section{Risk and Return Analysis}

a. From risk

In risk point of view, risk of Equity Mutual Fund is higher than Balanced Mutual Fund. Return always correlated with risk; it means if investors need high return, they also must take high risk. 
b. In return point of view, Equity Mutual Fund provides higher return but fluctuated compare to Balanced Mutual Fund. Balanced Mutual Fund has an asset allocation which consists of money market (Cash, SBI and Deposit) is 5\% - 30\%, equity is $50 \%$ - $95 \%$ and bond is $0 \%-20 \%$, whereas portfolio of Equity Mutual Fund consist of money market is $0 \%-20 \%$ (Cash, SBI and Deposit) and equity is $80 \%-100 \%$. In case JCI and LQ 45 index decrease, there are other instruments like money market and bond that will support the index of Balanced Mutual Fund.

\section{Balanced Mutual Fund}

a. From Return, most products of Balanced Mutual Fund that being analyzed have the lowest return in 2008 exclude Optima Fleksi and Simas Danamas Fleksi that still gives positive return. The lowest return is caused by global financial crisis as explained in Chapter V. All products of Balanced Mutual Fund that being analyzed with its launched dates before 2005, their return decreased quite significant in 2005 compare to 2004. The products are Batavia Si Dana Dinamis, Manulife Dana Campuran, Bahana Dana Infrastruktur and Danareksa Anggrek. In 2005, it can cause by macroeconomic condition in Indonesia as explained in Chapter V.

b. From standard deviation (risk), the highest standard deviation (risk) is occurred in 2008. There are 3 (three) products which have the highest standard deviation from their launched date to December 2008. They are Bahana Dana Infrastruktur is $13.00 \%$, BNI Dana Fleksibel Dua is $12.84 \%$ and Mandiri Investasi Aktif is $11.31 \%$ with their increase in range from $6.5 \%$ to $8.2 \%$.

c. From sharpe ratio, the lowest Sharpe Ratio indicates a riskless asset would perform better than the security being analyzed. The highest Sharpe Ratio indicates the greater a portfolio's Sharpe ratio, the better its risk-adjusted performance has been. Most of product of Balanced Mutual Fund has the lowest Sharpe Ratio in 2008. There are 7 (seven) products which have the lowest Sharpe Ratio. They are Schroder Dana Terpadu II is -0.41 , Mandiri Investa Aktif is -0.43 , Batavia Si Dana Dinamis is -0.53 , Manulife Dana Campuran is -0.38 , Bahana Dana Infrastruktur is -0.46 , Danareksa Anggrek is -0.50 and BNI Dana Fleksibel Dua is -0.75 . And the 3 (three) others product have the lowest Sharpe Ratio in 2005. The products are Fortis Spektra is 1.12, Optima Fleksi is -3.58 and Simas Danamas Fleksi is -0.11 . This 2 (two) products decrease in range from 0.8 to 1.15 in average.

d. From Correlation Matrix analysis, all products of Balanced Mutual Fund have a strong correlation with JCI and LQ 45 Index. The value is above 0.8. It means Net Asset Value of these products will increase if JCI and LQ 45 increase or vice versa. There are 2 (two) products which have coefficient of correlation below 0.8 . The products are Simas Danamas Fleksi with coefficient of correlation with JCI is 0.717848 and with LQ45 is 0.664982 and BNI Dana Fleksibel Dua with coefficient of correlation with JCI is 0.649915 and with LQ45 is 0.676310 . It can cause by portfolio diversification which government bond is dominated in this two products and its portion more than $50 \%$.

e. From Vector Autoregression analysis, all NAV of Balanced Mutual Fund products have affected by both JCI and LQ 45 Index. It means that if JCI and LQ 45 Index increase, Net Asset Value of Balanced Mutual Fund's products increase too and vice versa. In this vector autoregression estimates, we use 2 lags analysis and 4 lags analysis. There are 6 (six) products which at $1^{\text {st }}$ until $4^{\text {th }}$ lag, have affected by both JCI 
and LQ 45 Index. The products are Fortis Spektra, Batavia Si Dana Dinamis, Bahana Dana Infrastruktur, Optima Fleksi, Sinarmas Danamas Fleksi and BNI Dana Fleksibel Dua. And the remaining products, JCI and LQ 45 Index might be not affect only at $1^{\text {st }}$ lag, but affect at $2^{\text {nd }}$ lag until $4^{\text {th }}$ lag.

\section{Equity Mutual Fund}

a. From return, most products of Equity Mutual Fund that being analyzed have the lowest return in 2008. The lowest return is caused by global financial crisis as explained in Chapter V. All products of Equity Mutual Fund that being analyzed with its launched dates before 2005, their return decreased quite significant in 2005 compare to 2004. The products are Schroder Dana Prestasi Plus, Fortis Ekuitas, Batavia Si Dana Saham, Manulife Dana Saham, Bahana Dana Prima and BNI Reksadana Berkembang. In 2005, it can cause by macroeconomic condition in Indonesia as explained in Chapter V.

b. From standard deviation (risk), the highest standard deviation (risk) is occurred in 2008. It is occurred because of global financial crisis as explained in Chapter V. If the product of Equity Mutual Fund gives the higher return and it must also compensate with higher risk.

c. From sharpe ratio, the lowest Sharpe Ratio indicates a riskless asset would perform better than the security being analyzed. The highest Sharpe Ratio indicates the greater a portfolio's Sharpe ratio, the better its risk-adjusted performance has been. All product of Equity Mutual Fund has the lowest Sharpe Ratio in 2008. It occurred because of global financial crisis as explained in Chapter V.

d. From Correlation Matrix analysis, all products of Equity Mutual Fund have a strong correlation with JCI and LQ 45 Index. The value is above 0.8. It means Net Asset Value of these products will increase if JCI and LQ 45 increase or vice versa.

e. From Vector Autoregression analysis, all NAV of Equity Mutual Fund products have affected by both JCI and LQ 45 Index. It means that if JCI and LQ 45 Index increase, Net Asset Value of Equity Mutual Fund's products increase too and vice versa. In this vector autoregression estimates, we use 2 lags analysis and 4 lags analysis. There are 6 (six) products which at at $1^{\text {st }}$ until $4^{\text {th }}$ lag, have affected by both JCI and LQ 45 Index. The products are Fortis Ekuitas, Mandiri Investasi Atraktif, Batavia Si Dana Saham, Danareksa Mawar Agresif, Optima Saham, Simas Danamas Saham. And the remaining products JCI and LQ 45 Index might be not affect at $1^{\text {st }}$ lag, but affect at at $2^{\text {nd }}$ lag until $4^{\text {th }}$ lag.

\section{REFERENCES}

Berk, Jonathan \& De Marzo, Peter. (2007). Corporate Finance. International Edition. New Jersey: Pearson.

Bodie, Kane, \& Marcus. (2008). Investments, 7th edition International Edition. Singapore: Mc.Graw Hill.

Levine, Stephan, Krehbiel \& Berenson. (2005). Statistic for Managers, 4th edition. New Jersey: Prentice Hall. 
Seiler, Michael J. (2004). Performing Financial Studies: A Methodological Cookbook. New Jersey: Pearson.

Siamat, Dahlan. (2005). Manajemen Lembaga Keuangan, 5th edition. Jakarta: Lembaga Penerbit Fakultas Ekonomi Universitas Indonesia.

http://www.bapepam.go.id/pasar_modal/publikasi_pm/info_pm/warta/2005_desember/Perkem bangan\%20Reksa\%20Dana.pdf

http://www.bus.1su.edu/economics/papers/pap97_27.pdf

www.bapepam.go.id

www.finansialbisnis.com

www.idx.co.id

www.investopedia.com

www.infovesta.com

www.kompascetak.com

www.korantempo.com

www.okstate.edu

www.stata.com 